Animal Health Research Institute (AHRI)

Assiut Lab.

\title{
SEROLOGICAL INVESTIGATIONS FOR DETECTION OF CHLAMYDIA INFECTION IN ABORTED CATTLE IN ASSIUT GOVERNORATE
}

(With 3 Tables)

\author{
By \\ MARIUM F. MANSY; S.M. SAYED and \\ S.M. EL BERBAWY \\ (Received at 6/2/2010)
}

فحوصات سيرولوجية للتعرف على مدى انتثار الإصابة بميكروب الكلاميديا في الأبقار في محافظة ملئ أسيوط الإنط

مريم فؤاد منسي ، سبل محمد سبل ، سعد محروس البرباوى

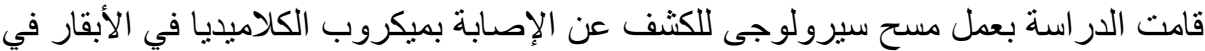

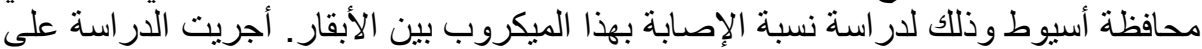

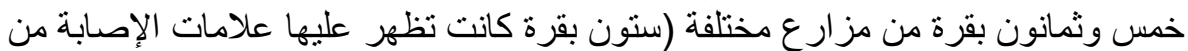

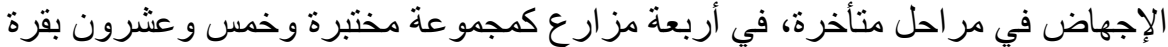

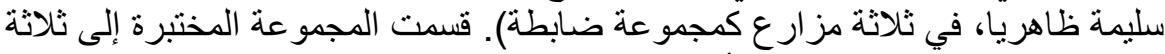

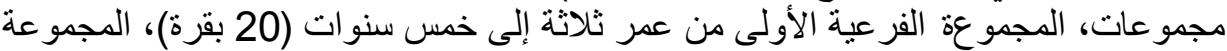

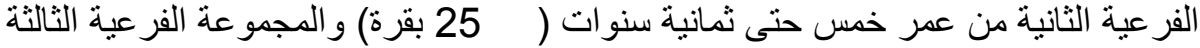

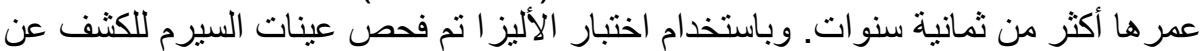

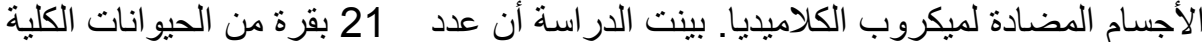

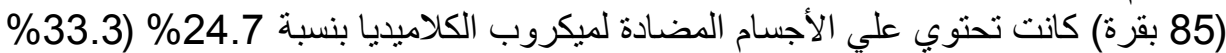

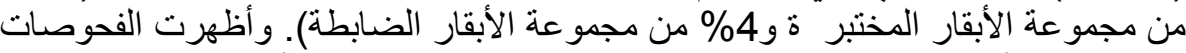

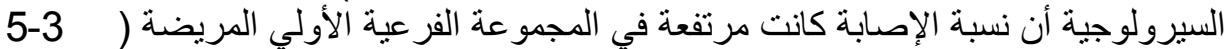

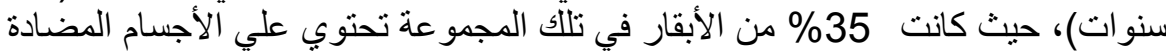

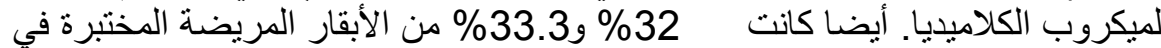

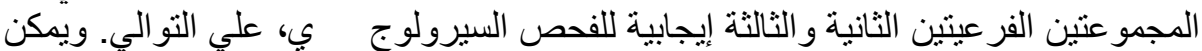

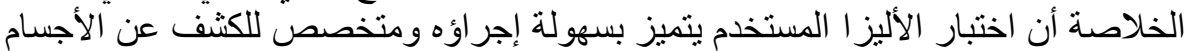
المضادة لميكروب الكلاميديا في عينات السيرم للأبقار ، ترى الدراسة الدة أن هذا الاختبار ملائم

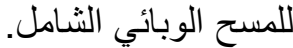




\section{SUMMERY}

Serological study was carried out on the chlamydial related infections in cattle at Assiut Governorate. Eighty five cows in different localities were examined (sixty cows with reproductive disorders in four farms as tested group and twenty five clinically healthy cows in three different farms as a control group). The diseased tested cows were divided into three subgroups; the first tested subgroup (20 cows) with age 3-5 years; the second tested subgroup ( 25 cows) with age 5-8 years and the third tested subgroup (15 cows) with age more than eight years. Blood samples were taken from each animal with different ages (three years to more than eight years). Samples were examined for both IgG and IgM Chlamydia antibodies with an indirect ELISA. Twenty-one cows of the total examined cows (85) were serologically positive for both IgG and IgM Chlamydia antibodies with a percentage $24.7 \%$ (33.3\% of the diseased tested cows and $4 \%$ of the clinically healthy cows). The serological investigation referred that the infection was higher in diseased tested cows at age 3-5 years; where $35 \%$ of these tested cows were serologically positive for both IgG and IgM Chlamydia antibodies. Also seropositivity was $32 \%$ and $33.3 \%$ of the diseased tested cows in the second (5-8 years) and the third ( $>8$ years) tested subgroups, respectively. It can be concluded that the enzyme immunoassay (ELISA) was easily to perform and can used as rapid screening test for detection of recent, latent chlamydial infections and apparently healthy cows.

Key words: Chlamydia psittaci, ELISA, cattle, abortion.

\section{INTRODUCTION}

The Chlamydiaceae are ubiquitous through out the world and infect both humans and animals. The obligate intracellular bacteria exhibit a unique life cycle with two morphologically different infectious and reproductive forms: The elementary body (EB) and reticular body (RB) forms (Rekiki, et al., 2002).

Phylogenetic analysis based on 16 S-23 S ribosomal RNA sequences has led to the classification of the Chlamydiaceae family into two genera: Chlamydia and Chlamydophila (Everett, et al., 1999).

Chlamydiphila abortus and other Chlamydia are the most important causative agent of the enzootic abortion infections in cattle, 
sheep and goat. It may also impair the over all reproductive performance. The organism has a zoonotic potential, and therefore must be dealt with great care with adequate microbiological precautions and laboratory containment (Travnicek, et al., 2003). In cattle infections with Chlamydophila abortus can cause illnesses like pneumonia, genital infections, abortion, enteritis, keratoconjunctivitis, polyarthritis, encephalomyelitis and mastitis (Abd El-Rahim, 2002 and Twomey, et al., 2006).

Examination of field samples indicated regular clinical inapparent chlamydial infections in cattle breeds. Clinically abortions occur in the last months of pregnancy or the production of weak and generally premature calves. Abortions due to chlamydial infections have major economic implications in ruminant breeding. Infected cattle often excreted Chlamydia with their feces which play an important role for further spreading of the infection for other animals (Wittenbrink, et al., 1993).

Diagnosis of Chlamydia infections depends on laboratory examinations for chlamydial antigen and / or antibodies detection. Serological methods could be used for diagnosis of latent and chronic chlamydial infections through detection of the specific persistent antibodies. All chlamydiae carry a common diagnostically relevant cellwall lipopolysaccharide (LPS)-antigen, which can be detected by both monoclonal and polyclonal antibodies (Ward and Ridgway, 1998).

In case of direct EIA (Enzyme Immuno Assay) test, enzyme labeled antibodies that recognize all species of Chlamydia bind to LPS extracted from elementary bodies in the specimen. In indirect EIA test it detects reactivity to genus specific antigen, or LPS, of chlamydial elementary or reticulate bodies (Moss, et al., 1993). The indirect ELISA was efficient useful screening test for Chlamydial abortion on the flock level, performed well, being more easier, sensitive and specific. It is of great help for the epidemiological control of the disease (Longbottom, et al., 2001; Buendia, et al., 2001 and McCauley, et al., 2007).

The present study aimed to investigate the incidence of Chlamydia related abortions in cattle during breeding seasons also to compare seroprevalence to Chlamydia psittaci in aborted cow populations and in a randomly selected control group. 


\section{MATERIALS and METHODS}

\section{Materials:}

\section{Samples:}

Blood samples were collected from eighty-five cows from different farms in Assiut Governorate (sixty cows with a history of abortion within the previous seasons in four farms as a tested group and twenty-five apparently healthy cows without a history of abortion as a control group).

The tested group cows(60) was subdivided into three subgroups according to their age; the first tested subgroup (20 cows) were from 3-5 years; the second tested subgroup (25 cows) were from 5-8 years and the third tested subgroup (15 cows) were over eight years.

Sample collection: (according to Black, et al., 1997).

1. The animal was examined clinically; symptoms and data including the number of animal, animal's owner, or name of the farm, age of the cattle, and its general conditions were recorded.

2. $5 \mathrm{ml}$ blood sample was collected from coccygyal vein from each examined animal.

3. Blood samples were centrifuged for ten minutes at $4000 \mathrm{rpm}$ and separated sera were stored at $-20^{\circ} \mathrm{C}$ in epindorf tube.

4. Indirect enzyme linked immunosorbent assay (ELISA) ChlamyEIA Vierotech ELISA kit for detection of antichlamydia serum IgG and IgM antibodies against Chlamydia psittaci commercially supplied from Human Company -Germany.

\section{Preparation of reagents used in ELISA:-}

1. Dilution of RF sorbent, $5 \mathrm{ul}$ from tested serum was added to $50 \mathrm{ul} \mathrm{RF}$ reagent and 445 ul diluting buffer to give a final dilution of 1:100 in a sterile epindorf tube and mixed well by vortex.

2. Dilution of the antibovine conjugate in a ratio 1:100 was done using a diluting buffer which in the ELISA kit. 4950 ul diluting buffer was added to $50 \mathrm{ul}$ antibovine conjugate.

\section{Methods:}

\section{Detection of IgM, IgG antichlamydia antibodies by ELISA:}

- Principles of EIA virotech ELISA:-

The ELISA was intended for semiquantitave detection of $\mathrm{IgG}$, IgM in serum. The antibodies form an immune complex with the antigen coated on the test strips. Unbounded immunoglobulins were removed by 
washing processes. After adding the substrate solution (TMB), a blue dye was produced by the bound enzyme (peroxidase), the colour changed to yellow when the stopping solution was added.

\section{Preparation of reagents:-}

1- All reagents were brought to room temperature before opening package of microtiter strips.

2- All liquid components were shaked well before use.

3- Washing solution concentrate had to be filled up to one liter with double distilled water.

High IgG titer disturbs the specific detection of $\operatorname{IgM}$ antibodies and may cause false negative or false positive results. For proper IgM determination it was therefore necessary to treat sera with RF - sorbent.

\section{Procedure:}

1- For each test run, 100 ul each of ready to use dilution buffer were pipetted (blank), IgG and IgM positive, negative and cut off controls.

2- The working dilution of the serum samples was 1:100.

3- The test plate after pipetting were incubated for $30 \mathrm{~min}$ at $37^{\circ} \mathrm{C}$ (with cover).

4- The microtiter strips were washed four times with 300 ul washing solution per well. All residues were removed on a cellulose pad.

5- $100 \mathrm{ul}$ of diluted antibovine $\mathrm{IgG}$ and $\mathrm{IgM}$ conjugate were dispensed to each well and were incubated for $30 \mathrm{~min}$ at $37^{\circ} \mathrm{C}$ with cover .

6- Conjugate incubation was stopped by washing several times.

7- $100 \mathrm{ul}$ of ready to use TMB were pipetted into each well.

8- In dark place the substrate solution was added then incubated for 30 min at $37^{\circ} \mathrm{C}$ with cover.

9- The substrate reaction was stopped with 50 ul of citrate stopping solution in each well, the plate was shacked carefully and thoroughly until mixed completely and a homogeneous yellow color was visible.

10- Optical density (OD) was measured at $450 / 620 \mathrm{~nm}$. The photometer was set such a way that the blank value was deducted from all other extinctions.

Statistical data analysis was done using Chi-square by SPSS, 2005 program (Statistical Package for Social Sciences for Windows Release 14.0.0.). 


\section{RESULTS}

Table 1: Serological results of ELISA for antichlamydia IgG and IgM of different age groups.

\begin{tabular}{|c|c|c|c|c|c|}
\hline \multirow{2}{*}{ Group } & \multirow{2}{*}{$\begin{array}{c}\text { No. of examined } \\
\text { cows }\end{array}$} & \multicolumn{4}{|c|}{ Serological results } \\
\hline & & positive & $\%$ & negativ & $\%$ \\
\hline \multirow{4}{*}{$\begin{array}{l}\text { Tested group } \\
\text { aborted cows } * *\end{array}$} & $\begin{array}{l}\text { Subgroup (1) } 20 \text { cows } \\
\text { from 3-5 years* }\end{array}$ & 7 & 35 & 13 & 65 \\
\hline & $\begin{array}{l}\text { Subgroup (2) } 25 \\
\text { cows from 5-8 years* }\end{array}$ & 8 & 32 & 17 & 68 \\
\hline & $\begin{array}{l}\text { Subgroup ( } 3 \text { ) } 15 \\
\text { cows more than } 8 \\
\text { years } *\end{array}$ & 5 & 33.3 & 10 & 66.6 \\
\hline & 60 cows & 20 & 33.3 & 40 & 66.7 \\
\hline \multirow{4}{*}{$\begin{array}{l}\text { Clinically } \\
\text { healthy } \\
\text { cows** }\end{array}$} & 8 cows (3-5 years) & 0 & 0 & 8 & 100 \\
\hline & 10 cows $(5-8$ years $)$ & 1 & 10 & 9 & 90 \\
\hline & 7 cows (>8 years) & 0 & 0 & 7 & 100 \\
\hline & 25 cows & 1 & 4 & 24 & 96 \\
\hline Total & 85 cows & 21 & 24.7 & 64 & 75.3 \\
\hline
\end{tabular}

* No statistical difference $\chi^{2}=0.045 \quad \mathrm{p}=0.978$

** Highly significant statistical variations $\chi^{2}=8.163 \quad \mathrm{p}>0.004$

Table 2: Results of ELISA for detection of antichlamydial IgG in sera of tested cows of different age group:

\begin{tabular}{|l|l|llll|}
\hline \multirow{2}{*}{ Age group } & Number of cows & \multicolumn{4}{|c|}{ ELISA Results } \\
& & positive & $\%$ & negative & $\%$ \\
\hline 3-5 years & 20 & 3 & 15 & 17 & 85 \\
\hline 5-8 yeas & 25 & 5 & 20 & 20 & 80 \\
\hline$>8$ years & 15 & 4 & 26.7 & 11 & 73.3 \\
\hline Total & 60 & 12 & 20 & 48 & 80 \\
\hline
\end{tabular}


Table 3: Results of ELISA for detection of antichlamydial IgM antibodies in sera of tested cows of different age group:

\begin{tabular}{|l|l|llll|}
\hline Age group & Number of cows & \multicolumn{4}{|c|}{ ELISA Results } \\
& & positive & $\%$ & negative & $\%$ \\
\hline 3-5 years & 20 & 4 & 20 & 16 & 80 \\
\hline 5-8 yeas & 25 & 3 & 12 & 22 & 88 \\
\hline$>8$ years & 15 & 1 & 6.7 & 14 & 93.3 \\
\hline Total & 60 & 8 & 13.3 & 52 & 86.7 \\
\hline
\end{tabular}

\section{DISCUSSION}

Chlamydophila abortus and other chlamydial infections is the most important causative agent of abortions of cattle. It responsible for a multiplicity of syndromes such as polyarthritis, keratoconjunctivitis, mastitis. The frequency of the latent infection and the difficulties of diagnosis, prophylaxis as well as treatment of Chlamydia infections cause a number of field problems to veterinarians, Abd El-Rahim (2002). Serological methods for examination of cattle herds are necessary, so ELISA was often preferred because it was easy to perform, its higher sensitivity and specificity for detection of Chlamydia antibodies in bovine sera, (Sting and Hafez, 1992).

Table (1) showing that 21 cows $(24.7 \%)$ out of totally 85 cows were serologically positive for antichlamydial antibodies IgG or IgM. This result is nearly similar to that obtained by Schmatz, et al. (1978) in Egypt (22\%) and Abd El-Rahim (2002) in North East Germany (19.6\%). The high rate of Chlamydia infection (68\%) was recorded in Germany by Sting and Hafez (1992). The present study showing that the tested cows at age 3-5 years had high titer of both antichlamydial IgG and $\operatorname{IgM}$, as $35 \%$ of these tested cows were serologically positive. This result was nearly similar to findings of Abd El-Rahim, (2002) who carried out a serological survey on the Chlamydia infection in cattle dairy herds in Germany and he concluded that the infection was more frequent among young cows (3-6 years). Also Sting and Hafez (1992) concluded that chlamydial infections were more frequent among young cows.

The serological investigation in the present work, Table (1), referred that $32 \%$ and $33.3 \%$ of the tested cows subgroup two (5-8 years) and subgroup (3) (>8 years) were positive, respectively, this may 
due to LPS ELISA are superior for serodiagnosis of ruminant infections with abortigenic Chlamydia and this result was in agreement with those of Kaltenboeck, et al. (1997), Baud, et al. (2008) and Pantchev, et al. (2009), they concluded that mixed chlamydial infections were not rare and suggested an extended host range of individual species and probably emerging obstetrical pathogens.

The results of ELISA in the serum samples of apparently healthy control cows, as showing in Table (1), showing that one cow out of (25) cases with percentage of (4\%) was serologically positive. Cavirani, et al. (2001) compared between seroprevalnce to Chlamydia psittaci in aborted cow populations (45\%) and in the control group (24\%).

Table (2) shows the results of ELISA for antichlamydia IgG in the sera of tested cattle of different age groups, the infection was higher among cattle at age more than eight years (4)cows (26.7\%) out of (15) cows were serologically positive, this due to old age cows at which latent and chronic chlamydial infection were high, this result emphasized the results of Wang, et al. (2001) who found that $71 \%$ of aborted cows had IgG against Chlamydia abortus in sera of tested cattle. Travnicek, et al. (2003) concluded that there is a significant level of IgG antibodies against Chlamydia abortus was detected up to eight weeks after abortion or parturition and a rise in antibodies titer provides a basis for retrospective diagnosis. Detection of specific IgG antibodies in aborted bovine sera against Chlamydia psittaci using indirect ELISA revealed $39.1 \%$ positive seroreactors, Ghazy, et al. (2005).

Table (3) shows that antichlamydia IgM was higher in tested cows at age three to five years with percentage of $20 \%$ this due to the recent chlamydial infections, this result was in agreement with findings of Wehrend, et al. (2000) and Wang, et al. (2001), they investigated the prevalence of Chlamydia psittaci infections in cattle farms with fertility disorders and determined Chlamydia specific IgM antibodies in sera of tested cattle. Also they found that with increased incidence of abortions showed detectable antichlamydia antibodies and in follow up examinations seroconversion show increase in $\mathrm{IgG}$ titer in these farms the results support the hypothesis that there was a high prevalence of latent Chlamydia infection in cattle.

It can be concluded that the enzyme immunoassay (ELISA) was easily to perform and can used as rapid screening test for detection of recent, latent chlamydial infections and apparently healthy cows. 


\section{REFERENCE}

Abd El-Rahim, I.H.A. (2002): Serological investigations for determination of the spreading of the Chlamydia infection in cattle in North East Germany; $10^{\text {th }}$ Sci. cong. Fac. Vet. Med., Assiut Univ., Egypt, 308-317.

Baud, D.; Regan, L. and Greub, G. (2008): Emerging role of Chlamydia and Chlamydia -like organisms in adverse pregnancy outcomes. Curr. Opin. Infect. 21(1): 70-76.

Black, C.M. (1997): Current method of laboratory diagnosis of Chlamydia trachomatis infections. Clin. Micro. Rev.; 10: 160-184.

Buendia, A.J.; Cuello, F.; Rio, L. and Caro, M. (2001): Field evaluation of a new commercially available ELISA based on a recombinant antigen for diagnosing Chlamydia psittaci infection. Vet. Microbiol. 78: 29-239.

Cavirani, S.; Cabassi, C.S.; Donofrio, G.; De Iaco, B.; Taddei, S. and Flammini, C.F. (2001): Association between Chlamydia psittaci seropositivity and abortion in Italian dairy cows. Prev. Vet. Med. 19: 50 (1-2): 145-151.

Everett, K.D.; Bush, R.M. and Andersen, A.A. (1999): Emended description of the order chlamydiales, proposal of Para chlamydiaceae fam. Nov. and Simkaniaceae Fam. Nov., each containing one monotypic genus, revised taxonomy of the family chlamydiacae, including a new genus and five new species, standard for the identification of organisms. Int. J. Syst. Bacter. 49: 415-440.

Ghazy, A.A.; Ghazi, Y.A. and Effat, M.M. (2005): Studies on infectious abortion in dairy cattle in Egypt. J. Egypt. Vet. Med. Assoc., 65(2): 147-166.

Kaltenboeck, B.; Heard, D.; De Graves, F.J. and Schmeer, N. (1997): Use of synthetic antigens improves detection by enzyme linked immunosorbent assay of antibodies against abortigenic Chlamydia psittaci in ruminant. J. Clin. Micro. 35(9): 2293-2298.

Longbottom, D.; Psarrou, E. and Livingstone, M. (2001): Diagnosis of ovine enzootic abortion using an indirect ELISA based on a recombinant protein fragment of the polymorphic outer membrane protein of Chlamydophilia abortus (C. psittaci). FEMS-Microb. Letters, 195: 157-161. 
McCauley, L.; Lancaster, M.; Young, P.; Butler, K. and Ainsworth, C. (2007): Comparison of ELISA and CFT assay for Chlamydophila abortus antibodies in ovine sera. Aust. Vet. J., 85(8): 325-328.

Moss, T.R.; Darougar, S.; Woodland, R.M.; Nathan, M.; Dianes, R.J. and Cathrine, V. (1993): Antibodies to Chlamydia species in patients attending a genitourinary clinic and the impact of antibodies to $C$. pneumoniae and $C$. psittaci on the sensitivity and specificity of $C$. trachomatis serology tests. Sex. Transm. Dis.; 20: 61-65.

Pantchev, A.; Sting, R.; Bauer, Feind, R.; Tyczka, J. and Sachse, K. (2009): Detection of all chlamydophila and Chlamydia spp. of veterinary interest using species specific real time PCR assay. Comp. Imm. Micro. Infect. Dis. 4: 234-239.

Rekiki, A.; Sidi-Boumedine, K.; Souriau, A.; Jemli, J.; Hammami, S. and Rodolakis, A. (2002): Isolation and characterization of local strains of Chlamydophila abortus (Chlamydia Psittaci Serotype) from Tunisia. Vet. Res. 33: 215-222.

Schmatz, H.D.; Krauss, H.; Viertel, P.; Ismail, A.S. and Hussein, A.A. (1978): Seroepidemiologische Untersuchungen zum Nachwies von AntikÖrper gegen Rickettsien und Chlamydien bei Hauswiederkauem in Ägypten, Somalia und Jordanien. Acta Trop. 35(2): 101-111.

Sting, R. and Hafez, H.M. (1992): Nachwies von Antikorper gegen Chlamydia psittaci bei puten und rindern mit Hilfe von ELISA und Komplement bindungsreation. Tagung der fachgruppe Backteriologie und bakterielle Krankheiten. DVG, Marburg. pp. 113-122.

Travnicek, K.M; Kovacova, D.; Bhide, M.R.; Zubricky, P. and Cislakova, L. (2003): Detection of IgG Antibodies against Chlamydophila abortus in sheep with reproductive disorders. Acta Vet. Brno, 72: 95-99.

Twomey, D.; Griffiths, P.; Horigan, M.; Hignett, B. and Martin, T. (2006): An investigation into the role of Chlamydophila spp. in bovine upper respiratory tract disease. Vet. J., 171(3): 574-576.

Wang, Q.; Ciu, B.; Wang, Z.; Zhong, J.; Yu, F.; Zhang, J. and Yang, Y. (2001): Isolation and identification of pathogens from sows with Chlamydia abortion in Honghe Prefect is Yuman. Chinese. J. of Vet. Science and Technology, 31(1)19-20. 
Ward, M.E. and Ridgway, G. (1998): Chlamydia .In. Topley and Welson's Microbiology and Microbial Infections, $9^{\text {th }}$ edition. (eds. Collier, I.; Balows, A. and Sussman, M. Volume (2), Systematic Bacteriology (eds. Balows, A. and Durden, B.) Chapter (59) The Bath Press, Avon, Great Britain, pp. 1331-1346.

Wehrend, A.; Bleul, U.; Jager, C. and Bostedt, H. (2000): Prevalence of Chlamydia psittaci infections in cattle of farms with fertility disorders. Tieraztliche Praxis, 28: 80-83.

Wittenbrink, M.M.; Bisping, W.; Morzek, M. and Holchler, H. (1993): Die intestinale Chlamydia psittaci - infection des Rind: Häufigkeit sowie technische Aspekte des Kultuellen erregernachwieses. Dtsch. Tierärztl. Wschr. 100: 195-198. 